\title{
A Perspective Study of Women Micro-Entrepreneurs in the Rural Areas of Osun State, Nigeria
}

\author{
V. Karthihai Selvi ${ }^{1}$ and S. Muthupandi ${ }^{2}$ \\ ${ }^{1}$ Principal Investigator and Assistant Professor, Department of Commerce \\ ${ }^{2}$ Project Fellow, ICSSR-IMPRESS, Post and Research Department of Commerce \\ ${ }^{1 \& 2}$ Ayya Nadar Janaki Ammal College, Sivakasi, Tamil Nadu, India \\ E-mail: selvikarthi85@gmail.com,smpanjac@gmail.com
}

\begin{abstract}
The socio-economic contributions of rural-women entrepreneurs in many countries have not been properly captured in the right perspective. Consequently, the economic potentials of this category of rural dwellers have been underutilized. This empirical study highlights some salient features of these entrepreneurs and their microenterprises. Their demographic characteristics as well as motivation factors, among others, were collected from a purposive sample of one hundred- and fifty-women micro-entrepreneurs from five rural areas in Aiyedire Local government Area (LGA) of Osun state using structured questionnaires. The interview technique, alongside a consideration of relevant extant literatures was also utilized to increase the richness of the data obtained. The information obtained in the survey was analyzed using simple descriptive statistical tools with the support of the computer statistical software SPSS 14.0.In conclusion, the women micro-entrepreneurs make significant contributions to the socio-economic well-being of their families, the rural communities as well as the country at large. It is recommended that for such contributions to be more substantial, the entrepreneurial capabilities of these women need to be further enhanced through gender specific supports that are rural friendly.
\end{abstract}

Keywords: Rural, Woman-Entrepreneur, Micro-Enterprise, Entrepreneurship

\section{INTRODUCTION}

The interest of scholars on women micro-enterprises and entrepreneurship is increasingly gaining significance. The contributions of women at the start-up and growth of micro, small and medium enterprises and hence towards the socioeconomic development of many countries is substantial (United Nations, 2006; Kjeldsen and Nielson, 2000). Sani and Danwanka (2011) also attest to the increasing number of women-owned enterprises. The emergence of womenowned enterprises as significant economic agents in the society is important in the empowerment process of the women particularly for those in the rural.In Nigeria, more than half of the populace lives below the poverty line and $70 \%$ live in the rural parts ofthe country (Oluwasola, 2010; Olawoye, 2007). Women make up the majority of the unemployed and poverty inclined. Consequently, many governments and at the three tiers (federal, state and local) are increasing their policy attention at microentrepreneurship, particularly as it pertains to women. Furthermore, women are the majority, as owners or workers in these rural-based micro-enterprises. Why is this so? The demographic of these women is evident. Many are unschooled, have little or no economic skills and are therefore confined to the traditional activities of child bearing and home-keeping. For the rural-based women, they may in addition to the above, be involved in farmassistance activities to their husbands. From the foregoing, it is evident that a clear understanding of women microenterprises is important; otherwise, by now we should have an industrialized rural economy in Nigeria. Consequently, this research intends to shed more light on the women micro-entrepreneurs at the rural areas in Nigeria. Specifically, the paper addresses the motivation, sources of start-up fund and the nature of these micro-enterprises. The issues to be addressed in this paper are important and certainly will contribute to on-going efforts at increasing the opportunities for women's economic participation at the national, state and local levels to alleviate poverty, reduce unemployment and the attainment of the Millennium Development Goals (MDGs).

\section{THEORETICAL FRAMEWORK}

It is necessary to examine some underlying concepts that will enable a better understanding of the phenomenon being profiled i.e. Women micro-entrepreneur and microenterprise. This understanding begins from the proper delineation of what a micro-enterprise is from the small, medium and large-scale enterprises. Like the concept of entrepreneurship, there is no widely acclaimed definition of a micro-enterprise (Akande et al., 2011, El-Goharyet al., 2008). Also, it is pertinent to point out the fact that even within the same agency or country, the definition changes from time to time. Consequently, the definition can be said to be individual-, country-, institution- or agency-specific. However, a consensus can be noticed on the characteristics or measures used to define these enterprises. The definitions of micro, small, medium or large enterprise used by scholars as well as policymakers/governments centers typically on the number of employees, initial capital outlay, the volume of sales, the asset base, some financial metrics and so on. For many Nigerian scholars, that includes Ladanu (2009), Olutunla and Obamuyi (2008), the number of employees is a significant criterium. For instance, the National Council of Industries in 2001 and on the basis of the number of 
employees considered the micro/cottage enterprise as one with an employee size of not more than ten, small-scale enterprise; between 11 and 100, medium scale; between101 and 300; and large scale, above 300 workers. In addition to the employee size, this body also used the total cost in defining these enterprises. In view of the above, the position of the authors is that an enterprise having less than five employees is a micro-enterprise. On the characteristics of micro-enterprises, Yeshiareg (2008) opine these enterprises have a small level of capitalization, are owner-managed, use simple equipment, locally available resources and with informal transaction relationships with customers. This is typical of Nigerian enterprises. These enterprises are mainly unregistered and therefore do not fall within the purview of the government's regulation. The enterprises mainly operate in the informal sector. However, these "tiny enterprises" opines Mohanty (2004), "have promising potential for creating self-employment avenues for multitude of rural population having low and moderate skill and providing scope for productive utilization of available natural and local resources”. While recognizing the importance of these enterprises, many measures have been taken by the Nigerian governments to facilitate the ease of operation these firms. This include the establishment of various financing schemes, the Small Industries Credit Fund, Microfinance Banks, Family Economic Advancement Programme and the setting up of industrial zones (Ike, 2006; Ariyo, 2005). A new start-up technology- based entrepreneur with good intention of contributing to economic growth and development is posed with the challenge of inadequate capital to run the business (Ayedun\&Ladanu,2013). Furthermore, for the woman micro-entrepreneur, that is, a female that operates a micro-enterprise, family labours are mainly utilized and there is very little specialization. Such women that are in the rural areas can be said to have an innovative attitude and the right motivation for operating an enterprise (Sidhu and Kaur, 2006). In other-words, such women perform their domestic chores that include taking care of children, care of their husbands and the elderly as well as participate in the running of an enterprise (Pandi, 2011). Consequently, women can be seen to be playing crucial roles in the sustenance of all aspects of the rural economy.

\section{METHODOLOGY}

This paper employed the survey type of research method that involves the use of both primary and secondary data. The secondary sources of data involved the use of relevant journals, conference papers from the electronic and print media, including archival data. The primary data were obtained through the use of a pre-tested questionnaire. Also, unstructured interviews were conducted to further clarify and complement the information gathered through the questionnaire. The questionnaire has open-ended and closeended questions on the respondents' bio-data and relevant issues of interest to this study. The questionnaire was read to the women micro-entrepreneurs by the research assistants, since many of these respondents were illiterates.
Also, a Professor and two senior academic experts in the field of entrepreneurship moderated the questionnaire. A total of 150 women micro-entrepreneurs was purposively sampled from the five rural communities in Aiyedire Local Government Area of Osun state. The sample obtained was subjected to simple descriptive statistical analysis using the Statistical Package for the Social Sciences (SPSS 16.0) software.

\section{RESULTS AND DISCUSSION}

This study is empirical and concerns the women microentrepreneurs in the rural area. The findings from the demographic characteristics of the entrepreneurs are presented below. Table I reveals that the majority of the women micro-entrepreneurs' age ranges between 41 to 50 years (approximately 35.30\%). About 23.30\% were aged between 31 and 40 years. The lowest figure was obtained forewomen above 60 years, that is, approximately $8.70 \%$ of the sampled women. This is an indication that the women in this age bracket will prefer handing their enterprises to the junior ones.

TABLE I AGE DISTRIBUTION OF SAMPLED WOMEN MICROENTREPRENEURS

\begin{tabular}{|c|c|c|c|}
\hline Sl. No. & Age & $\begin{array}{c}\text { No. of } \\
\text { Respondents }\end{array}$ & Percentage (\%) \\
\hline 1 & Below 20 & 5 & 3.30 \\
\hline 2 & 21 to 30 & 20 & 13.30 \\
\hline 3 & 31 to 40 & 35 & 23.30 \\
\hline 4 & 41 to 50 & 53 & 35.30 \\
\hline 5 & 51 to 60 & 24 & 13.00 \\
\hline 6 & Above 60 & 16 & 8.70 \\
\hline \multicolumn{2}{|c|}{ Total } & 150 & 100 \\
\hline
\end{tabular}

The educational level of the sampled women microentrepreneurs (Table II), highlights majority $58.70 \%$ of the respondents are studied above $12^{\text {th }}$ standard and $3.30 \%$ of the respondents are studied below $5^{\text {th }}$ standard in the study area.

TABLE II EDUCATIONAL QUALIFICATION OF RESPONDENTS

\begin{tabular}{|c|c|c|c|}
\hline Sl. No. & $\begin{array}{l}\text { Educational } \\
\text { Qualification }\end{array}$ & $\begin{array}{c}\text { No. of } \\
\text { Respondents }\end{array}$ & $\begin{array}{c}\text { Percentage } \\
(\%)\end{array}$ \\
\hline 1 & Below 5 & 5 & 3.30 \\
\hline 2 & 5 to 8 & 15 & 10.00 \\
\hline 3 & 8 to 10 & 32 & 21.30 \\
\hline 4 & 10 to 12 & 10 & 6.70 \\
\hline 5 & Above 12 & 88 & 58.70 \\
\hline \multicolumn{2}{|r|}{ Total } & 150 & 100 \\
\hline
\end{tabular}


With respect to the marital position (Table III), more than half (approximately $92.67 \%$ ) are married and $7.33 \%$ are unmarried.

TABLE III MARITAL STATUS OF SAMPLED WOMEN

\begin{tabular}{|c|l|c|c|}
\hline Sl. No. & $\begin{array}{c}\text { Marital } \\
\text { Status }\end{array}$ & $\begin{array}{c}\text { No. of } \\
\text { Respondents }\end{array}$ & $\begin{array}{c}\text { Percentage } \\
\text { (\%) }\end{array}$ \\
\hline 1 & Married & 139 & 92.67 \\
\hline 2 & Unmarried & 11 & 7.33 \\
\hline \multicolumn{2}{|r|}{ Total } & 150 & 100 \\
\hline \multicolumn{2}{|c}{ Source: Primary Data }
\end{tabular}

On the motivating factors for enterprise ownership (Table IV), reveals the majority of the women (56.00\%) claimed the reason was to improve on their family income. Other women micro-entrepreneurs reported $14.00 \%$ as desire for autonomy, to increase status in society, $8.00 \%$ and the inducement to obtain benefits from the government/state assisted programs, approximately $2.70 \%$. It is important to note the absence of opportunity-based factors such as the availability of market. Motivating factors are important to understand the success/failure of enterprises. More importantly, it is necessary to understand what factors lead women to initiate and launch a business or enterprise.

TABLE IV MOTIVATING FACTORS FOR BUSINESS OWNERSHIP

\begin{tabular}{|c|l|c|c|}
\hline Sl. No. & \multicolumn{1}{|c|}{ Factors } & $\begin{array}{c}\text { No. of } \\
\text { Respondents }\end{array}$ & Percentage (\%) \\
\hline 1 & Make money & 29 & 19.30 \\
\hline 2 & Improve income & 84 & 56.00 \\
\hline 3 & Independence & 21 & 14.00 \\
\hline 4 & Increase status & 12 & 8.00 \\
\hline 5 & Government Assistance & 4 & 2.70 \\
\hline & Total & 150 & 100 \\
\hline
\end{tabular}

Women operate several micro-enterprises that take many forms including trading, food processing, simple technology-related production activities that are mainly Agric-related and so on. As revealed in Table V, approximately $46.70 \%$ of the women are engaged in the selling of Agric-related products, $4.00 \%$ in services that includes tailoring, operating female hair salons, $16.00 \%$ operate restaurants, $5.30 \%$ operate simple production activities involving the processing of palm products and $28.00 \%$ operate stores to sell some company manufactured products. In addition to the operating of stores, some women were found to be engaged in offering services at weddings/parties besides renting out the necessary tools for such engagements

TABLE V TYPE OF MICRO-ENTERPRISE

\begin{tabular}{|c|l|c|c|}
\hline Sl. No. & \multicolumn{1}{|c|}{ Types } & $\begin{array}{c}\text { No. of } \\
\text { Respondents }\end{array}$ & Percentage (\%) \\
\hline 1 & Trading & 42 & 28.00 \\
\hline 2 & Sell food & 24 & 16.00 \\
\hline 3 & Sell agricultural production & 70 & 46.70 \\
\hline 4 & Services & 6 & 4.00 \\
\hline 5 & Manufacturing & 8 & 5.30 \\
\hline \multicolumn{2}{|c|}{ Total } & 150 & 100 \\
\hline
\end{tabular}

On the sources of start-up capital, the majority of the women micro-entrepreneurs, $123.00 \%$ utilized self-funds from Table VI. Also, friends/relatives are not left out at assisting the women entrepreneurs at the start-up phase.

Approximately, $19.00 \%$ of the micro-enterprises utilized this source. Also, the use of co-operatives or Self-Help Groups (SHGs) was utilized was utilized by the women micro-entrepreneurs, approximately $8.00 \%$. It is pertinent to note the non-utilization of any microfinance bank or any form of government assisted capital schemes. This is in line With the position of Gate wood et al., (2004) that women prefer personal capital than borrowing to start and operate an enterprise. It is equally important to note that access to loans has been found to have positive impact on the profit of the enterprise in Nigeria (Ojo, 2009). Consequently, one can imagine the impact on these women operated enterprises. 
TABLE VI SOURCES OF START-UP CAPITAL

\begin{tabular}{|c|l|c|c|}
\hline Sl. No. & Sources & No. of Respondents & Percentage (\%) \\
\hline 1 & Owner's fund & 123 & 123.00 \\
\hline 2 & Relations & 19 & 19.00 \\
\hline 3 & Co-operatives & 8 & 8.00 \\
\hline 4 & Bank/Govt. & 0 & 0.00 \\
\hline 5 & Bank/Govt. & 0 & 0.00 \\
\hline \multicolumn{2}{|c|}{ Total } & 150 & 100 \\
\hline \multicolumn{2}{r}{} & & Source: Primary Data \\
\hline
\end{tabular}

On the problems associated and consequently being encountered by the women micro-entrepreneurs Table VII, approximately $45.30 \%$ consider finance as the major impediment to the success of their enterprises. This is similar to the findings of Francis et al., (2006) in the study of women in Northern Ireland and that of Heino (2006) with respect to the micro-enterprise creation in Mexico. The results of this study furthermore indicate access to market (28.00\%), access to information access (11.30\%), inadequate skills (approx. 8.70\%) and technology (6.70\%) as the problems associated with the operation of their enterprises. It needs to be stated emphatically that generally women have low skills hence they operate mostly in the informal sectors of many developing countries

TABLE VII PROBLEMS ASSOCIATED WITH OPERATION OF MICRO-ENTERPRISE

\begin{tabular}{|c|l|c|c|}
\hline Sl. No. & \multicolumn{1}{|c|}{ Problems } & No. of Respondents & Percentage (\%) \\
\hline 1 & Finance & 68 & 45.30 \\
\hline 2 & Market Access & 42 & 28.00 \\
\hline 3 & Information Access & 17 & 11.30 \\
\hline 4 & Inadequacy Skills & 13 & 8.70 \\
\hline 5 & Technology & 10 & 6.70 \\
\hline \multicolumn{2}{|c|}{ Total } & 150 & 100 \\
\hline \multicolumn{2}{|r}{}
\end{tabular}

\section{CONCLUSION AND RECOMMENDATION}

Micro-enterprises and in particular women-owned or operated enterprises are important at meeting the challenges of empowering women, generating employment and enhancing national productivity. The findings from the research indicate the rural women are engaged in different types of enterprises using mainly self-sourced start-up capital and from a background of different motivations. In consonance with any capitalist intensions, the women micro-entrepreneurs no doubt aim to develop some degree of economic independence and achieve other social and personal objectives through their ownership and operation of these enterprises. However, much needs to be done and is being desired such that the sense of achievement, leadership quality, economic and social empowerment as well as enhanced positive contributions to national development can still be achieved. It is the opinion of the researchers that the entrepreneurial capabilities and competencies of the women can further be enhanced having first indicated their interest through ownership and operation of microenterprises. Consequently, the relevant agencies, at The various levels of government administration and nongovernmental organizations are enjoined to have a holistic look at the training and improvement of the orientations of these entrepreneurs. This will at the end, make them successful, act as springboard for other indigenous female entrepreneurs as well as contribute meaningfully to the industrialization and economic growth of the country. With the right motivations from these sources, including family members, the capacities of the women micro-entrepreneurs will be strengthened with positive ripple effects on family income as well as to the economy at large.

\section{REFERENCES}

[1] Ayedun, T. A. \& Ladanu, W. K. (2013). Finance as a Critical Success Factor in the Establishment and Sustainability of Entrepreneurial Ventures", International Journal of Advance Research in Statistics, Management and Finance, 1(2), 88-97.

[2] Oluwasola, O. (2010). Stimulating Rural Employment and Income for Cassava (Manihot sp) Processing farming Households in Oyo State Nigeria through Policy Initiatives, Journal of Development and Agricultural Economics, 2(2), 018-025.

[3] El-Gohary, H., Trueman, M. \& Fakukawa, H. (2008). E-marketing and Small Business Enterprises: A Review of the Methodologies, Journal of Business \& Public Policy, 2(2), 64-93.

[4] Ladanu, W. K. (2009), Sustainable Development and Financing of Small and Medium Enterprises in Nigeria: The Journey So Far", Journal of Business Administration and Management, 4(1), 43-49. 
[5] Olutunla, G. T. \& Obamuyi, T. M. (2008). An Empirical Analysis of Factors Associated with the Profitability of Small and Mediumenterprises in Nigeria, African Journal of Business Management, 2(1), 195-200.

[6] Sani, M. H. \& Danwanka, H. A. (2011). Economic Analysis of Women Soap Making Agri-business Enterprises and Family Sustenance in Kogi State, Nigeria, Asian Journal of Rural Development, 1(1), 54-62.

[7] Gatewood, Brush, Carter, Greene \& Hart (2004). Women Entrepreneurs, Growth and Implications for the Classroom, USA: Coleman Foundation Whitepaper Series for the USA Association for Small Business and Entrepreneurship.

[8] Ike, M. (2006), The Background Information Concerning the Definition, Size and Characteristic Features of the SMEs in Nigeria, In Alison, G. (2006). Towards an African E-index on SME E-access and Usage across 14 African Countries. www.reachICTafrica.net, 4044.

[9] Ariyo, D. (2005). Small Firms are the Backbone of the Nigerian Economy, www.Africaeconomicanalysis.org/article/gen/smallhtm. html. Accessed on Shane (2003). A general theory of entrepreneurship: The individual-opportunity nexus. UK: Edward Elgar.

[10] Kjeldsen J. \& Nielson K. (2000). The Circumstances of Women Entrepreneurs, Danish Agency for Trade and Industry, November. http://www.ebst.dk/publikationer/rapporter/women_entrepreneurs/ka p04.html

[11] Sidhu, K. \& Kaur, S (2006). Development of Entrepreneurship among Women, Journal of Social Science, 13(2), 147-149. 